\title{
Effect of Milk Quality and Stabilizers on Some Physicochemical Properties of UHT-Milk
}

\author{
El-Sayed ${ }^{1}$, M. I., Amel A. Ibrahim ${ }^{2}$, \& Awad ${ }^{2 *}$, S. \\ 1 Department of Dairy Technology Research, Food Technology Research Institute, ARC, Egypt. \\ 2 Department of Dairy Science and Technology, Faculty of Agriculture, Alexandria University, Egypt.
}

Received: 21 March, 2018

Revised: 8 May, 2018

Accepted: 15 May, 2018

\begin{abstract}
Milk quality and stabilizers were investigated to revere their effects on undesirable changes in sensory of UHT milk as influenced by storage at $25^{\circ} \mathrm{C}$ or $37^{\circ} \mathrm{C}$. The obtained results showed that the total microbial count, psychrophilic bacteria, mesophilic \& thermophilic spore forming bacteria were higher in grade B (GB) milk than in grade A (GA) milk. Seven treatments were carried out with GA, GB, reconstituted full cream milk powder (FCMP), FCMP mix with GA and GB milk, meanwhile, two commercial stabilizers were separately evaluated. Mesophilic and thermophilic spore forming bacteria exhibited high scores and were found in standardized pasteurized GB milk comparing with GA milk. The type of stabilizer has no any effect on the UHT milk quality. The treatments of UHT milk made using GB milk received low levels of sensory properties (color \& flavor), as well as, fat separation and sedimentation could be noted during storage when compared to that made from GA milk or FCMP. The fat separation and sedimentation were more pronounced in treatments stored at $37^{\circ} \mathrm{C}$ when compared to that stored at $25^{\circ} \mathrm{C}$. Results of SDS-PAGE and RP-HPLC did not show any significant differences among all treatments in proteolysis during storage period. Accordingly' the fat separation and sedimentation were not related only to proteolysis but were related to quality of milk used in processing.
\end{abstract}

Key words: UHT milk, sedimentation, fat separation, milk stabilizers.

\section{INTRODUCTION}

The manufacture of almost all types of milk and its products involves one or more heat treatments. The aim of heat treatments is to kill microorganisms and inactivate enzymes "partially or fully" dependent on type of heat treatment. This is done to secure safety of consumer along with extension of shelf life of the dairy product. Heat treatment can, however, also cause certain undesirable changes like production of brown pigments, development of cooked flavour and loss of nutrients (Walstra et al., 1999, Kessler 2002). UHT treatment is a technological process used to produce drinking milk that is microbiologically safe and its shelf life ranges between 6-12 months at room temperature and stability of casein micelles during their storage (Deeth, 2010, Baglinière et al., 2012). Normally, UHT treatment is carried out at a range of $135-150^{\circ} \mathrm{C}$ for $1-10 \mathrm{~s}$ as a holding time required to achieve 'commercial sterility' (Chen et al., 2015). UTH milk is stable for long-term storage at ambient temperatures if microbiological sterility has been achieved by the UHT treatment and maintained by aseptic packaging (Kelly \& Fox 2012). The UHT milk processed by indirect systems show low sediment formation than its counterpart from direct systems, but sedimentation increased with elevating heat treatment and temperature of storage in direct UHT-milk (Datta, et al., 2002). Age gelation is a main factor reduces the shelf-life of UHT milk. It can be explained by a two-stage process involving formation of a $\beta$-lactoglobulin-kcasein complex during heating which cross-links after partial or complete release from the micelle of casein to forming a protein network gel. Proteolysis, by native milk proteinase (plasmin) or bacterial proteinases, increase gelation as a result of facilitating release of the complex from the micelle of casein-. Plasmin is sufficiently heat-stable enzyme to play a key role in term of age gelation of UHT milk, especially with direct UHT processing

\footnotetext{
* Corresponding author: Sameh Awad

Department of Dairy Science \& Technology, Faculty of Agriculture (El-Shatby), Alexandria University, Egypt

Tel \& Fax: 002035903915

e.mail: sameh111eg@yahoo.com
} 
(McMahon,1996). The activators of plasmin are not affected by pasteurization and are only slightly inactivated by ultra-high temperature processing conditions $\left(140^{\circ} \mathrm{C} / 32 \mathrm{~s}\right.$ ) (Deharveng \& Nielsen 1991). Addition of polyphosphates retard gelation by inhibiting formation of the protein network. Gelation can be minimized by using high quality (low somatic cells and bacterial count) raw milk, inactivating proteinases, increasing the severity of heat treatment, storing the UHT milk at temperatures lower or higher than room temperature, and or adding polyphosphates (Datta \& Deeth , 2001). UHTmilk proteolysis causes the development of bitter flavors and leads results in increase the viscosity, with formation a gel. These changes are caused, or at least accelerated, by hydrolysis of caseins, releasing the $\beta$-lactoglobulin-k-casein complex ( $\beta \mathrm{k}-$ complex) from the micelle. The released protein complex aggregates and forms a three-dimensional network of cross-linked proteins to cause a formation a gel (McMahon, 1996).

The UHT milk demand is increasing worldwide. It possesses many advantages regarding milk include distribution and storage at ambient temperature without needs cooling system. But undesirable changes could be occurred in UHT milk such as sedimentation, gelation, fat separation, cooked flavor and browning to limit its shelf life. In Egypt, about $20 \%$ of milk is produce from animals under good hygienic conditions. Milking machine is used, and the milk is cooled directly after milking, this milk is classified under grade A milk. The other $80 \%$ are produced from small herds composed of 1 to 5 lactating animals milked tow times a day. The obtained milk contains microorganisms' extremely high numbers due to poor hygienic practices during hand milking in the outdoors and milk handling practices, this milk is classified under grade B milk. Notwithstanding, raw milk used in processing UHT milk in Egypt is insufficient. So, reconstituted milk is used at $100 \%$ or mixed with raw milk. The present study aimed to evaluate the effect of milk quality on physicochemical and sensorial properties of UHT milk produced under the common conditions.

\section{MATERIALS AND METHODS}

\section{Materials}

Raw cow's milk GA was obtained from the good dairy farm located in the governorate of Gharbia, Egypt, while raw cow's milk GB was obtained from the milk collection center located in the governorate of Gharbia, Egypt. Full fat milk powders (FFMP) and skimmed milk powders (SMP) were obtained from Fonterra Company, New Zealand. Super Midagel "milk stabilizer" contains mono \& di-glyceride of fatty acids was obtained from Misr Food Additives (MIFAD) Company, Cairo. Lacta 760 R "milk stabilizer" contains mono \& di-glyceride of fatty acids and carrageenan was obtained from Misr Food Additives (MIFAD) Company, Cairo. Trifluoroacetic acid for HPLC grade and Acetonitrile for HPLC grade were obtained from SDS, Peypin, France and Scharlau, Barcelona, Spain, respectively. Acrylamide (2X) was obtained from SERVA Feibiochemia, New York,USA. Methanol and TMED were obtained from Sigma-Aldrich (St. Louis, MO,USA). Ammonium persulphate and Glycine were obtained from Oxford, India.

\section{Methods}

\section{Experimental and UHT- milk processing}

Raw milks either GA, GB were passed throw Bactofuge (Tetra Pack) at $60^{\circ} \mathrm{C}$, then standardized to $3.2 \%$ fat and $8.5 \%$ SNF by adding SMP, while $100 \%$ reconstituted milk was prepared by reconstitution of FFMP at level of $12.5 \%$ to get $3.2 \%$ fat and $8.5 \%$ SNF. Some treatments of mixing raw milk and milk powder were conducted by mixing standardized raw milk and reconstituted milk at level of 1:1. The milk stabilizers were added at level of $125 \mathrm{~g} /$ ton for Super Midagel and $700 \mathrm{~g} / \mathrm{ton}$ for Lacta 760R (Table 1). All standardized milks were pasteurized at $75^{\circ} \mathrm{C} / 15 \mathrm{sec}$ and kept at $4^{\circ} \mathrm{C}$ until UHT processing in not more than $30 \mathrm{hr}$.

UHT of milk was processed using direct heating (infusion, $\mathrm{APV}, \mathrm{USA}$ ) at $142^{\circ} \mathrm{C}$ for $6 \mathrm{sec}$ and

Table 1: Mixed treatments to produce UHT milks

\begin{tabular}{lll}
\hline No. & \multicolumn{1}{c}{ Treatments } & \multicolumn{1}{c}{ Stabilizer } \\
\hline 1 & Grade A Raw milk (100\%) & Midagel \\
2 & Grade B Raw milk (100\%) & Midagel \\
3 & Full fat milk powder (100) & Midagel \\
4 & $50 \%$ GA + FFMP & Midagel \\
5 & $50 \%$ GB + FFMP & Midagel \\
6 & $50 \%$ GA + FFMP & Lacta \\
7 & $50 \%$ GB + FFMP & Lacta \\
\hline
\end{tabular}

GA: Refer to milk which grade A, GB: Refer to milk which grad B, FFMP: refer to full fat milk powder 
homogenized at $200 \mathrm{~Pa}$. UHT milk was packed in tetra pack paper under aseptic conditions.

\section{Chemical analysis of UHT product}

Fat, protein, lactose and SNF contains were determined using Milko Scan FOSS FT2 (FOSS, Denmark). The $\mathrm{pH}$ value was determined using a digital $\mathrm{pH}$ meter (Mettler Toledo 320) at room temperature $\left(20 \pm 1^{\circ} \mathrm{C}\right)$ according to the AOAC (2007). The Titratable acidity was determined according to the AOAC (2007).

\section{Rheology analysis of UHT milk}

Viscosity was measured using oscillatory viscometer (VR 3000M YR Viscometers, Spain), using spindle 1 at speed of $60 \mathrm{rpm}$ at $10^{\circ} \mathrm{C}$.

\section{Microbiological analysis}

\section{Total viable count}

All samples of milk were serially diluted in peptone saline solution $(0.85 \%)$. The enumerations were done on nutrient agar (NA) medium. Plates were incubated at $30^{\circ} \mathrm{C}$ for $48 \mathrm{hr}$ under aerobic conditions (ISO 4833: 2003).

\section{Aerobic spore-forming bacteria}

Typical spore count tests involve the milk heating samples at $80^{\circ} \mathrm{C}$ for 10 min then cooled sudi denly to the room temperature before transferring one $\mathrm{ml}$ aliquots into petri dishes. The enumerations were done on plate count agar The plates were incubated at $32^{\circ} \mathrm{C} / 48 \mathrm{hr}$ (Standard Methods for the Examination of Dairy Products 2010).

\section{Thermo-Spore Forming bacteria}

The enumeration of colony-forming units (CFU) of resistant spores of thermophilic bacteria in UHT milk samples by using a colony-count technique at $55^{\circ} \mathrm{C}$ for $72 \mathrm{hr}$ after heating the sample at $106^{\circ} \mathrm{C}$ for $10 \mathrm{~min}$ (ISO/TS 27265:2009).

\section{Psychrophilic bacteria count}

The enumerations were done on nutrient agar (NA) medium. Plates were incubated at $7^{\circ} \mathrm{C}$ for 7 days.

\section{Sodium dodecyl sulphate polyacrylamide gel electrophoresis (SDS-PAGE)}

SDS-PAGE (12.5\%) technique was conducted using the discontinuous buffer system described by Laemmli (1970), and mentioned by Hames \& Rickwood (1990). The data were analyzed by total lab software (V1.11). To extract the total milk proteins, $25 \mathrm{ml}$ of cold ace- tone (stored overnight at $-20^{\circ} \mathrm{C}$ ) were added to $5 \mathrm{ml}$ of milk and stirred for $15 \mathrm{~min}$ by magnetic stirrer, then filtrated through filter paper and dried. While, about $5 \mathrm{~g}$ of milk gel that found at inner surface of the package wall was used of extraction to present the gel proteins.

\section{Preparation of UHT milk extracts (12\% TCA)}

Soluble extracts $(12 \%$ TCA) of UHT milk were prepared by adding TCA (24\%) to an equal volume of milk and mixing by vortexing for $5 \mathrm{~min}$ and then the mixture keeping at room temperature $\left(30^{\circ} \mathrm{C}\right)$ for $60 \mathrm{~min}$. The mixture was centrifuged at $8,000 \mathrm{xg}$ for $25 \mathrm{~min}$ at $4^{\circ} \mathrm{C}$ and the supernatants were filtered through filter paper Whatman 102 (Datta \& Deeth 2003).

\section{Analysis of peptides by RP-HPLC}

A HPLC system (Agilent Technologies 1260) at $40^{\circ} \mathrm{C}$ and a binary solvent gradient system at a flow rate of $1 \mathrm{ml} / \mathrm{min}$ and detection at $210 \mathrm{~nm}$ to analyse UHT milk peptides according to the method described by Datta \& Deeth (2003). Solvent A was $0.1 \%$ of trifluoroacetic acid in water $(\mathrm{v} / \mathrm{v})$ and solvent $\mathrm{B}$ was $0.1 \%$ of trifluoroacetic acid in acetonitrile $(\mathrm{v} / \mathrm{v})$. The proportion of solvent B was increased from $20 \%$ to $35 \%$ during the first $20 \mathrm{~min}$ and after $5 \mathrm{~min}$ raised to $65 \%$ in $20 \mathrm{~min}$ and finally to $100 \%$ in $5 \mathrm{~min}$. Samples were filtered through a 0.2-m membrane filter (Millipore Corp., Bedford, $\mathrm{MA})$. Injections of $50 \mathrm{ml}$ of filtrates samples were made by auto injector. Between samples the column was washed by increasing solvent B to $65 \%$ over $15 \mathrm{~min}$ and holding for $15 \mathrm{~min}$ and returning to $100 \%$ solvent $\mathrm{A}$.

\section{Sensory evaluations}

UHT milk samples were evaluated for sensory quality during the storage period at $0,30,60$ and 90 days by a panel of 10 members of researchers and postgraduate students at Dairy Science and Technology Department, Faculty of Agriculture (El-Shatby), Alexandria University. Samples were scored on a hedonic scale of 0-5 for colour, taste, fat separation and overall acceptability, according to the recommended protocol proposed by the ISO 22935-2:2009 (IDF 99-2:2009) for the sensory evaluation of milk products..

\section{Statistical analyses}

Data were subjected to analysis of variance by using Statistical Package for the Social Sciences (SPSS) program version 21. 


\section{RESULTS AND DISCUSSION}

\section{Physicochemical and microbiological prop- erties of raw ingredients}

The results in Table (2) showed that GB milk was significantly $(\mathrm{P} \geq 0.05)$ higher than GA milk in protein and SNF contents. There was no significant $(\mathrm{P} \leq 0.05)$ difference between GA and GB in fat $\%$. While the $\mathrm{pH}$ was significantly $(\mathrm{P} \geq 0.05)$ lower in GB than GA. Meanwhile, both milks (GA and GB) were negative for $75 \%$ Ethanol stability and the both milks were stable for UHT processing. There was a significant $(\mathrm{P} \geq 0.05)$ difference between $\mathrm{GA}$ and GB milks in total bacterial count, spore forming count and Psychrophilic bacteria (Table 3). Spore forming micro-organisms, mainly Bacillus spp caused microbial spoilage of heat treated milk (Mayr et al., 2004). So, raw milk grade affected on the microbial quality of used milk for processing UHT milk. The Physicochemical and microbiological specifications of GA milk were within the rang recommended by Egyptian Standard (2010), while the physical, chemical specification of GB milk were within the rang recommended by Egyptian Standard (2010) but it has higher level of total bacterial count (Table 2 and 3). Egyptian Standard (2010) recommended the fat and SNF should not less than 3 and $8.25 \%$ respectively, and the total bacteria count should be less than $300,000 \mathrm{CFU} / \mathrm{ml}$. The microbiological and chemical analyses of milk powder were within the range that recommended by Codex Alimentarius (2007) and Egyptian standard (2005). It's recommended the protein in dry basis should be not less than $34 \%$, moisture not higher than 5\%, and the total bacterial count should be less than $10,000 \mathrm{CFU} / \mathrm{g}$. The stabilizers that used in the present study have a good microbiological quality.

\section{Physicochemical and microbial analysis of milk and milk mixtures before UHT process (after standardization, pasteur- ization) and after UHT process.}

The results of physicochemical properties of milk after pretreatments (standardization, pasteurization) and after UHT process (Table 4) showed that there were no significant $(\mathrm{P} \geq 0.05)$ differences could be figured out in fat, lactose, SNF and acidity $\%$ among all treatments after standardization, pasteurization of milk. After UHT process, protein and fat contents were significantly, $(\mathrm{P} \leq 0.05)$ decreased when compared to the values before UHT process in the same treatments. The obtained results not agree with that reported by Burton (1994), who stated that during UHT milk production, the fat in milk does

Table 2: Physiochemical analyses of raw ingredients

\begin{tabular}{lccccc}
\hline \multirow{2}{*}{ Raw ingredients samples } & \multicolumn{5}{c}{ Mean* } \\
\cline { 2 - 6 } & $\mathrm{pH}$ value & $75 \%$ Ethanol stability & Fat $\%$ & Protein $(\mathrm{N} \times 6.38) \%$ & SNF $\%$ \\
\hline Raw milk GA & $6.4^{\mathrm{c}} \pm 0.01$ & - & $3.63^{\mathrm{b}} \pm 0.01$ & $3.32^{\mathrm{a}} \pm 0.01$ & $8.72^{\mathrm{a}} \pm 0.01$ \\
Raw milk GB & $6.2^{\mathrm{b}} \pm 0.01$ & - & $3.74^{\mathrm{b}} \pm 0.02$ & $3.34^{\mathrm{b}} \pm 0.05$ & $8.84^{\mathrm{b}} \pm 0.02$ \\
Full fat milk powder & $6.68^{\mathrm{a}} \pm 0.01$ & - & $25.8^{\mathrm{c}} \pm 1.81$ & $24.37^{\mathrm{c}} \pm 0.01$ & $71.1^{\mathrm{c}} \pm 0.1$ \\
Skimmed milk powder & $6.67^{\mathrm{a}} \pm 0.01$ & - & $0.54^{\mathrm{a}} \pm 0.01$ & $33.78^{\mathrm{d}} \pm 0.03$ & $95.67^{\mathrm{d} \pm 0.01}$ \\
\hline
\end{tabular}

*Means with the same letter(s) in the same column are not significant, but different letters are significant $(\mathrm{P}<0.05)$.

Table 3: Microbiological analysis of raw ingredients

\begin{tabular}{lllll}
\hline \multirow{2}{*}{ Raw ingredients samples } & \multicolumn{4}{c}{ Mean of Microbial count (log $\mathbf{1 0}_{10}$ cfu) } \\
\cline { 2 - 5 } & \multicolumn{1}{c}{$\begin{array}{c}\text { Total bacterial } \\
\text { count }\end{array}$} & $\begin{array}{c}\text { Meso-Spore Form- } \\
\text { ing bacteria }\end{array}$ & $\begin{array}{c}\text { Thermo-Spore } \\
\text { Forming bacteria }\end{array}$ & $\begin{array}{c}\text { Psychrophilic } \\
\text { bacteria }\end{array}$ \\
\hline Raw milk GA & $4.67 \mathrm{~d}$ & $2.08 \mathrm{a}$ & $1.30 \mathrm{a}$ & $2.90 \mathrm{a}$ \\
Raw milk GB & $6.54 \mathrm{e}$ & $2.86 \mathrm{e}$ & $1.73 \mathrm{~d}$ & $4.04 \mathrm{~b}$ \\
Full fat milk powder & $3.41 \mathrm{~b}$ & $2.54 \mathrm{c}$ & $2.07 \mathrm{e}$ & N.D. \\
Skimmed milk powder & $3.57 \mathrm{c}$ & $2.67 \mathrm{~d}$ & $1.81 \mathrm{~d}$ & N.D. \\
Super Mida gel & $3.08 \mathrm{a}$ & $2.14 \mathrm{a}$ & $1.32 \mathrm{~b}$ & N.D. \\
Lacta 760 R & $3.38 \mathrm{~b}$ & $2.39 \mathrm{~b}$ & $1.54 \mathrm{c}$ & N.D. \\
\hline
\end{tabular}

*Means with the same letter(s) in the same column are not significant, but different letters are significant $(\mathrm{P}<0.05)$. 


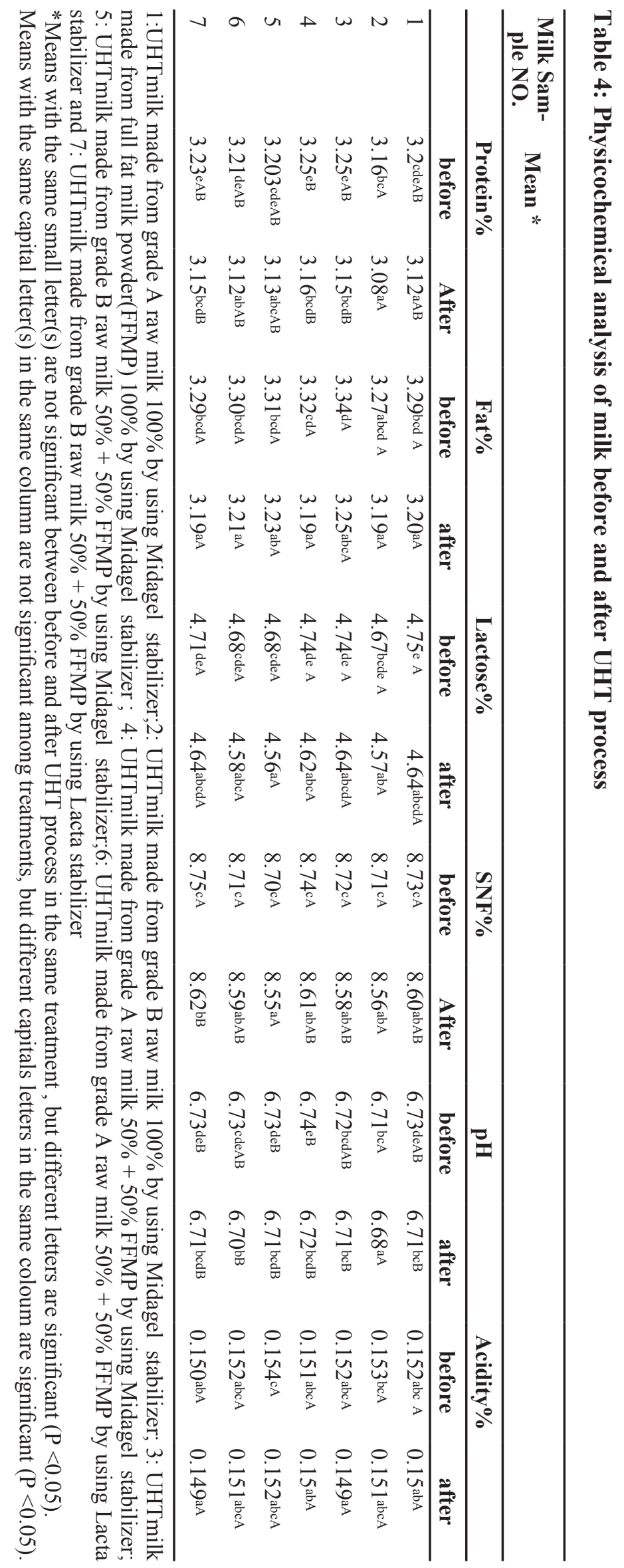


not change physically or chemically, so it cannot have adverse nutritional consequences. Such an effect could be related to the direct heating used in the present study rather than indirect heating used by Burton (1994). In addition, no significant $(\mathrm{P} \leq 0.05)$ differences were found in fat $\%$, lactose $\%$ and acidity $\%$ after UHT process among all treatments. From these results, it can be concluded that milk or stabilizer types have no any effect on the physical and chemical properties of UHT milk products.

The source of raw milk used in this study has a significant $(P \leq 0.05)$ effect on the count of mesophilic and thermophilic spore forming bacteria (Table 5). In general, all treatments used GB, either $100 \%$ or $50 \%$, have significant $(\mathrm{P} \leq 0.05)$ high level of mesophilic and thermophilic spore forming bacteria when compared with treatments used GA milk. Sample 7 (50\% GB with lacta) has the highest count of mesophilic spore forming bacteria but sample 4 (50\% GA with super medagel) has the lowest count. The log counts of thermophilic spore forming bacteria were 1.86 in sample $3(100 \%$ full fat milk powder). Whereas the log counts of thermo-spore forming bacteria in sample $1(100 \%$ milk grade A with super medagel) was 1.61 . No significant $(P$ $\geq 0.05$ ) differences were found between sample 2 (milk grade B with super medagel), sample 5 (50\% GB with super medagel) and sample 7 (50\% GB with lacta) in mesophilic and thermophilic - spore forming bacteria count. Stabilizer and full fat milk powder have no effect on the milk quality. Using of milk grade $\mathrm{B}$ and lacta stabilizer in mixture cause not significantly $(P \geq 0.05)$ increasing in mesophilic

Table 5: Microbiological analysis of milk after pre-treatments (after standardization, pasteurization)

\begin{tabular}{|c|c|c|}
\hline \multirow[b]{2}{*}{$\begin{array}{l}\text { Milk Samples } \\
\text { NO. }\end{array}$} & \multicolumn{2}{|c|}{ *Mean of Microbial count $\left(\log _{10} \mathrm{cfu}\right)$} \\
\hline & $\begin{array}{c}\text { Meso-Spore } \\
\text { Forming bacteria }\end{array}$ & $\begin{array}{l}\text { Thermo-Spore } \\
\text { Forming bacteria }\end{array}$ \\
\hline 1 & $2.28^{\mathrm{a}}$ & $1.61^{\mathrm{ab}}$ \\
\hline 2 & $2.56^{\mathrm{ab}}$ & $1.84^{\mathrm{bc}}$ \\
\hline 3 & $2.62^{\mathrm{b}}$ & $1.90^{c}$ \\
\hline 4 & $2.25^{\mathrm{a}}$ & $1.59^{\mathrm{a}}$ \\
\hline 5 & $2.49^{\mathrm{ab}}$ & $1.84^{\mathrm{bc}}$ \\
\hline 6 & $2.50^{\mathrm{ab}}$ & $1.86^{\mathrm{c}}$ \\
\hline 7 & $2.63^{b}$ & $1.83^{\mathrm{bc}}$ \\
\hline
\end{tabular}

*Means with the same letter(s) in the same column are not significant, but different letters are significant $(\mathrm{P}<0.05)$ and thermophilic spore forming bacteria. The only factor effects the microbial quality of milk samples was raw milk grade. After UHT process, all samples were sterilized and there were no any microbiological defects after streak plates from incubated samples for 5 days at 32 or $55^{\circ} \mathrm{C}$, the $\mathrm{pH}$ was not changed in samples incubated for 8 days at 32 or $55^{\circ} \mathrm{C}$. These results recommended that the mesophilic and thermophilic spore forming bacteria (max $\log 2.63$ of mesophilic and $\log 1.9$ of thermophilic) in used milk has no any effect on sterility of product by direct heating at $142^{\circ} \mathrm{C}$ for $6 \mathrm{sec}$.

\section{Changes of sensory evaluation and some physicochemical properties of UHT milk during storage}

The changes of fat separation, gelation, color, flavor, $\mathrm{pH}$ and viscosity during the storage at ambient temperature showed significant $(P \geq 0.05)$ differences among samples made from Grade A milk (sample 1 and 6) and Grade B milk (sample 2 and 7) in sensorial evaluation (Table 6). There are no significant $(P \geq 0.05)$ differences among samples made from GA milk and reconstituted milk (1:1) and GB milk and reconstituted milk (1:1) using Medagel stabilizer in all sensorial evaluation expect flavour. The sedimentation was not noticed in samples made from GA milk during the 90 days of storage, but it was noticed in samples made from GB milk after only 30 days and the sedimentation increased during storage. The sedimentation was noticed after 90 days of storage in samples made from 100\% reconstituted milk or GA and reconstituted milk (1:1) with Lacta stabilizer, but it was noticed after 30 days in samples made from $100 \%$ GB or GB and reconstituted milk (1:1).

The behavior of fat separation was similar with sedimentation as when the sedimentation increased or noticed the fat was also separated. The sedimentation and fat separation were affected by source of milk used in this study. There was a reduction in acceptability of colour in all treatments, but the reduction was much noticed in samples made from GB milk than in those made from GA milk. There were no significant differences $(P \geq 0.05)$ in flavour acceptability in fresh samples made from GA or GB milk, but the flavor acceptability was lower after 30 days till 90 days in samples made from GB milk than in samples made from GA milk. Milk made by $100 \%$ reconstituted milk or mixing of reconstituted milk with raw milk received low score of flavour acceptability when compared to samples made from 
Table 6: Sensory evaluation of UHT milk during storage at ambient temperature

\begin{tabular}{|c|c|c|c|c|c|c|}
\hline \multirow{2}{*}{$\begin{array}{l}\text { UHT Milk } \\
\text { samples }\end{array}$} & \multirow{2}{*}{$\begin{array}{c}\text { Time of storage } \\
\text { (days) }\end{array}$} & \multicolumn{5}{|c|}{ Sensory evaluation } \\
\hline & & $\begin{array}{l}\text { Sedimentation } \\
\text { (5 dgrees) }\end{array}$ & $\begin{array}{c}\text { Fat separation } \\
\text { (3 dgrees) }\end{array}$ & $\begin{array}{c}\text { Colour } \\
\text { (5 degrees) }\end{array}$ & $\begin{array}{c}\text { Flavour } \\
\text { (5 degrees) }\end{array}$ & $\begin{array}{c}\text { Appearance } \\
\text { (5 degrees) }\end{array}$ \\
\hline \multirow[t]{5}{*}{1} & 0 & $0^{\mathrm{a}}$ & $0^{\mathrm{a}}$ & $4.76^{p}$ & $5^{\mathrm{e}}$ & $4.83^{h}$ \\
\hline & 30 & $0^{\mathrm{a}}$ & $0^{\mathrm{a}}$ & $4.59^{\mathrm{no}}$ & $5^{e}$ & $4.79^{h}$ \\
\hline & 60 & $0^{\mathrm{a}}$ & $0^{\mathrm{a}}$ & $4.40^{\mathrm{jk}}$ & $5^{e}$ & $4.70^{\mathrm{h}}$ \\
\hline & 90 & $0^{\mathrm{a}}$ & $0^{\mathrm{a}}$ & $4.36^{\mathrm{hij}}$ & $4.36^{\mathrm{cd}}$ & $4.36^{\mathrm{g}}$ \\
\hline & Mean & $0^{\mathrm{D}}$ & $0^{\mathrm{E}}$ & $4.50^{\mathrm{A}}$ & $4.84^{\mathrm{A}}$ & $4.67 \mathrm{~A}$ \\
\hline \multirow[t]{5}{*}{2} & 0 & $0^{\mathrm{a}}$ & $0^{\mathrm{a}}$ & $4.32^{\mathrm{ghi}}$ & $5^{e}$ & $4.66^{\mathrm{h}}$ \\
\hline & 30 & $1^{b}$ & $1^{b}$ & $4.08^{e}$ & $4^{\mathrm{bc}}$ & $3.54^{\mathrm{c}}$ \\
\hline & 60 & $2^{c}$ & $2^{c}$ & $3.95^{\mathrm{cd}}$ & $4^{\mathrm{bc}}$ & $2.975^{b}$ \\
\hline & 90 & $2^{\mathrm{c}}$ & $3^{d}$ & $3.89^{\mathrm{bc}}$ & $3^{\mathrm{a}}$ & $2.445^{\mathrm{a}}$ \\
\hline & Mean & $1.25^{\mathrm{A}}$ & $1.5^{\mathrm{A}}$ & $4.06^{\mathrm{E}}$ & $4^{\mathrm{D}}$ & $3.405^{\mathrm{D}}$ \\
\hline \multirow[t]{5}{*}{3} & 0 & $0^{\mathrm{a}}$ & $0^{\mathrm{a}}$ & $4.58^{\mathrm{no}}$ & $4^{\mathrm{bc}}$ & $4.29 \mathrm{~g}$ \\
\hline & 30 & $0^{\mathrm{a}}$ & $0^{\mathrm{a}}$ & $4.45^{\mathrm{kl}}$ & $4^{\mathrm{bc}}$ & $4.225^{\mathrm{fg}}$ \\
\hline & 60 & $0^{\mathrm{a}}$ & $1^{b}$ & $4.24^{\mathrm{f}}$ & $3^{\mathrm{a}}$ & $3.62^{\mathrm{cd}}$ \\
\hline & 90 & $1^{\mathrm{b}}$ & $1^{b}$ & $3.84^{\mathrm{ab}}$ & $3^{\mathrm{a}}$ & $2.92^{b}$ \\
\hline & Mean & $0.25^{\mathrm{C}}$ & $0.5^{\mathrm{D}}$ & $4.27^{\mathrm{C}}$ & $3.5^{\mathrm{E}}$ & $3.76^{\mathrm{C}}$ \\
\hline \multirow[t]{5}{*}{4} & 0 & $0^{\mathrm{a}}$ & $0^{\mathrm{a}}$ & $4.49^{\mathrm{lm}}$ & $5^{e}$ & $4.74^{\mathrm{h}}$ \\
\hline & 30 & $1^{b}$ & $1^{b}$ & $4.26^{\mathrm{fg}}$ & $4.5^{\mathrm{cde}}$ & $3.88^{\mathrm{de}}$ \\
\hline & 60 & $1^{b}$ & $1^{b}$ & $4.01^{\mathrm{de}}$ & $4.5^{\mathrm{cde}}$ & $3.75^{\text {cde }}$ \\
\hline & 90 & $2^{c}$ & $2^{c}$ & $3.82^{\mathrm{ab}}$ & $4^{\mathrm{bc}}$ & $2.91^{b}$ \\
\hline & Mean & $0.916^{\mathrm{B}}$ & $1.083^{\mathrm{C}}$ & $4.14^{\mathrm{D}}$ & $4.5^{\mathrm{B}}$ & $3.82^{\mathrm{C}}$ \\
\hline \multirow[t]{5}{*}{5} & 0 & $0^{\mathrm{a}}$ & $0^{\mathrm{a}}$ & $4.53^{\mathrm{mn}}$ & $5^{e}$ & $4.76^{\mathrm{h}}$ \\
\hline & 30 & $1^{b}$ & $1^{b}$ & $4.31^{\mathrm{ghi}}$ & $4^{\mathrm{bc}}$ & $3.82^{\text {cde }}$ \\
\hline & 60 & $1^{b}$ & $2^{c}$ & $4.01^{\mathrm{de}}$ & $4^{\mathrm{bc}}$ & $3.50^{c}$ \\
\hline & 90 & $2^{c}$ & $2^{c}$ & $3.79^{a}$ & $4^{\mathrm{bc}}$ & $3.06^{\mathrm{b}}$ \\
\hline & & $0.83^{\mathrm{B}}$ & $1.1667^{\mathrm{C}}$ & $4.16^{\mathrm{D}}$ & $4.25^{\mathrm{C}}$ & $3.78^{\mathrm{C}}$ \\
\hline \multirow[t]{5}{*}{6} & 0 & $0^{\mathrm{a}}$ & $0^{\mathrm{a}}$ & $4.620^{\mathrm{p}}$ & $5^{e}$ & $4.81^{\mathrm{h}}$ \\
\hline & 30 & $0^{\mathrm{a}}$ & $0^{\mathrm{a}}$ & $4.50^{\mathrm{lm}}$ & $5^{e}$ & $4.75^{h}$ \\
\hline & 60 & $0^{\mathrm{a}}$ & $0^{\mathrm{a}}$ & $4.38^{\mathrm{ijk}}$ & $5^{e}$ & $4.69^{h}$ \\
\hline & 90 & $1^{\mathrm{b}}$ & $0^{\mathrm{a}}$ & $4.29^{\mathrm{fgh}}$ & $4.33^{\mathrm{cd}}$ & $3.81^{\mathrm{cd}}$ \\
\hline & & $0.25^{\mathrm{C}}$ & $0.083^{\mathrm{E}}$ & $4.45^{\mathrm{B}}$ & $4.83^{\mathrm{A}}$ & $4.51^{\mathrm{B}}$ \\
\hline \multirow[t]{5}{*}{7} & 0 & $0^{\mathrm{a}}$ & $0^{\mathrm{a}}$ & $4.45^{\mathrm{kl}}$ & $5^{e}$ & $4.72^{\mathrm{h}}$ \\
\hline & 30 & $1^{b}$ & $1^{b}$ & $4.26^{\mathrm{fg}}$ & $4.66^{\mathrm{de}}$ & $3.96^{\mathrm{ef}}$ \\
\hline & 60 & $1^{\mathrm{b}}$ & $2^{c}$ & $4.02^{\mathrm{de}}$ & $4.33^{\mathrm{cd}}$ & $3.67^{\mathrm{cde}}$ \\
\hline & 90 & $2^{c}$ & $2^{c}$ & $3.83^{\mathrm{ab}}$ & $3.66^{\mathrm{b}}$ & $2.91^{\mathrm{b}}$ \\
\hline & & $0.916^{\mathrm{B}}$ & $1.33^{\mathrm{AB}}$ & $4.14^{\mathrm{D}}$ & $4.41^{\mathrm{BC}}$ & $3.82^{\mathrm{C}}$ \\
\hline
\end{tabular}

1:UHTmilk made from grade A raw milk 100\% by using Midagel stabilizer;2: UHTmilk made from grade B raw milk 100\% by using Midagel stabilizer; 3: UHTmilk made from full fat milk powder(FFMP) 100\% by using Midagel stabilizer ; 4: UHTmilk made from grade A raw milk 50\% + 50\% FFMP by using Midagel stabilizer; 5: UHTmilk made from grade B raw milk 50\% $+50 \%$ FFMP by using Midagel stabilizer;6: UHTmilk made from grade A raw milk 50\% + 50\% FFMP by using Lacta stabilizer and 7: UHTmilk made from grade B raw milk 50\% + 50\% FFMP by using Lacta stabilizer

Means with the same letter(s) in the same column are not significant, but different letters are significant $(\mathrm{P}<0.05)$.

Capital letters refer to differences among treatments, Small letters: refer to differences among storage times in the same column. 
raw milk. The milk stabilizers used in this study has no effect on color and flavor acceptability of final UHT milk's made from GB milk. Using of lacta stabilizer has improvement flavor and color acceptability of samples made from GA and reconstituted milk (1:1). The change of UHT milk sensorial during storage referred to some reaction such as Maillard reaction, proteolytic activity (Renner 1988; Valero et al., 2001), lipid oxidation (Contarini et al., 1997). Thermal treatments of UHT milk cause aggregation of protein, fat and inorganic salts. These aggregates are sediment or/and clump on the surface of packaging. The sediment depends on some factors such as quality of raw milk, type and temperature/time of heat treatment, homogenizing pressure, homogenizer position and storage temperature. Sedimentation could be created after processing and during storage. Datta, et al. (2002) reported that direct UHT heating system usually case more sedimentation when compared to indirect heating system. Perkin, et al. (1973) reported that directly heated of UHT milk produced tow folds as much as sediment of indirectly processed milk. So, the direct heating system used in processing UHT milk in this study case increasing of the sedimentation of UHT GB milk which is mainly related to the low quality of raw milk and the storage temperature.

Viscosity of UHT milk samples was increased during storage (Fig.1). Fresh UHT milk made from
GA milk had lower viscosity than fresh samples made from GB. There were no significant differences $(P \leq 0.05)$ in viscosity of samples made from GA and GB milk after 30 days till 90 days. Viscosity changes may a direct phenomenon to age gelation and shelf stable of sterilized milk (Clare et al., 2005). Casein micelles play a key role in determining viscosity parameters of skim milk (Walstra \& Jenness 1984); therefore, any factor that affects the aggregation state of the micelle such as ionic strength, $\mathrm{pH}$, or heat would influence resistance to flow. $\mathrm{pH}$ values of UHT milk were slightly decreased during storage time (Fig. 2). UHT milk samples at 1 st day of storage has $\mathrm{pH} 6.68$, while the lowest $\mathrm{pH}$ value (6.61) for was observed in sample 3 after 90 days. So, this may be one of factors affected on increasing viscosity during storage.

\section{Changes of some physicochemical proper- ties and sensory evaluation of UHT milk during storage at different tem- perature}

There were significant differences $(\mathrm{P} \leq 0.05)$ among samples in colour, flavour and appearance acceptability during storage at different temperature $25^{\circ}$ and $37^{\circ} \mathrm{C}$ (Table 7). The reduction of colour was higher in samples stored at $37^{\circ} \mathrm{C}$ than that stored at $25^{\circ} \mathrm{C}$ especially with that made from GB milk. The reduction of colour was the highest in samples made

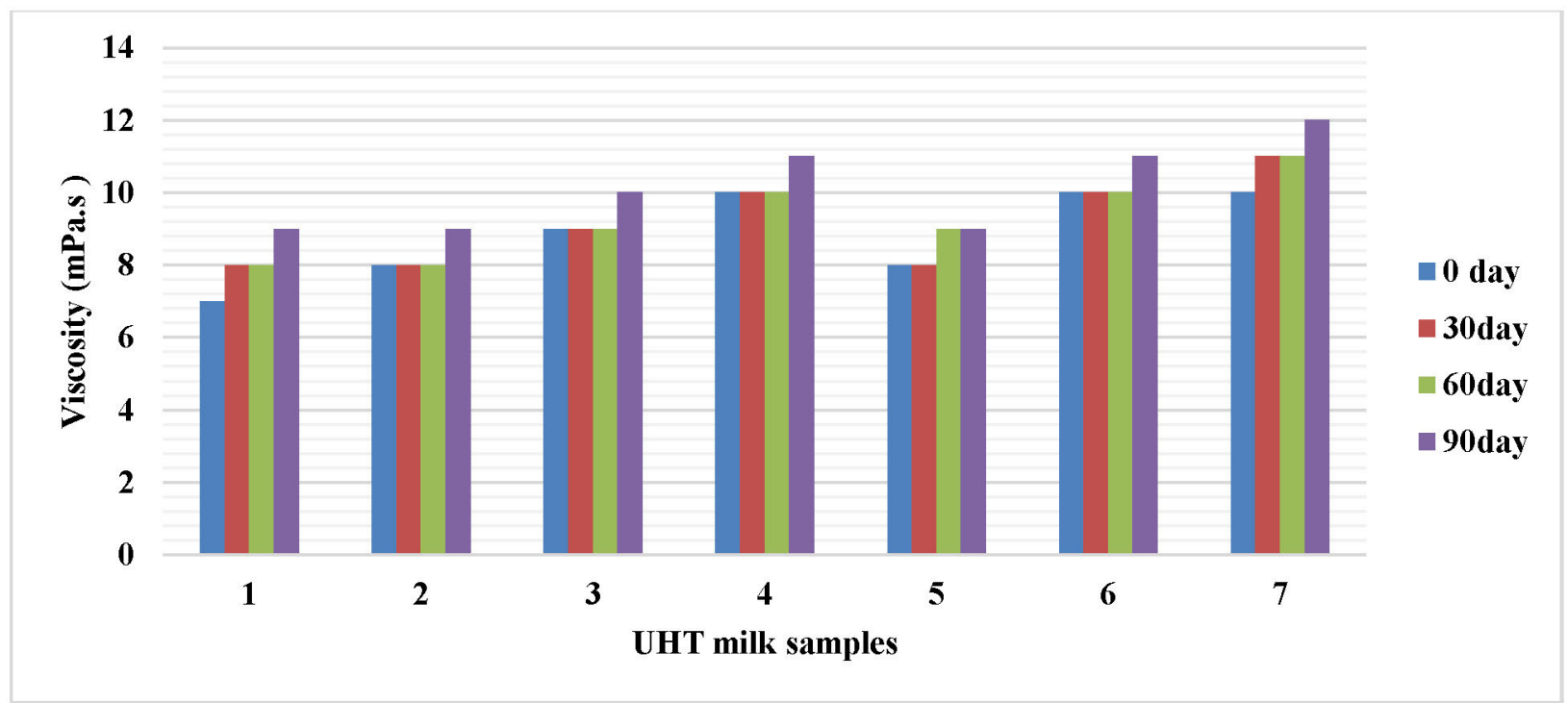

Fig.1: Change in viscosity of UHT milk samples during storage

1:UHTmilk made from grade A raw milk $100 \%$ by using Midagel stabilizer;2: UHTmilk made from grade B raw milk 100\% by using Midagel stabilizer; 3: UHTmilk made from full fat milk powder(FFMP) 100\% by using Midagel stabilizer ; 4: UHTmilk made from grade A raw milk 50\% + 50\% FFMP by using Midagel stabilizer; 5: UHTmilk made from grade B raw milk 50\% +50\% FFMP by using Midagel stabilizer;6: UHTmilk made from grade A raw milk 50\% +50\% FFMP by using Lacta stabilizer and 7: UHTmilk made from grade B raw milk 50\% $+50 \%$ FFMP by using Lacta stabilizer 


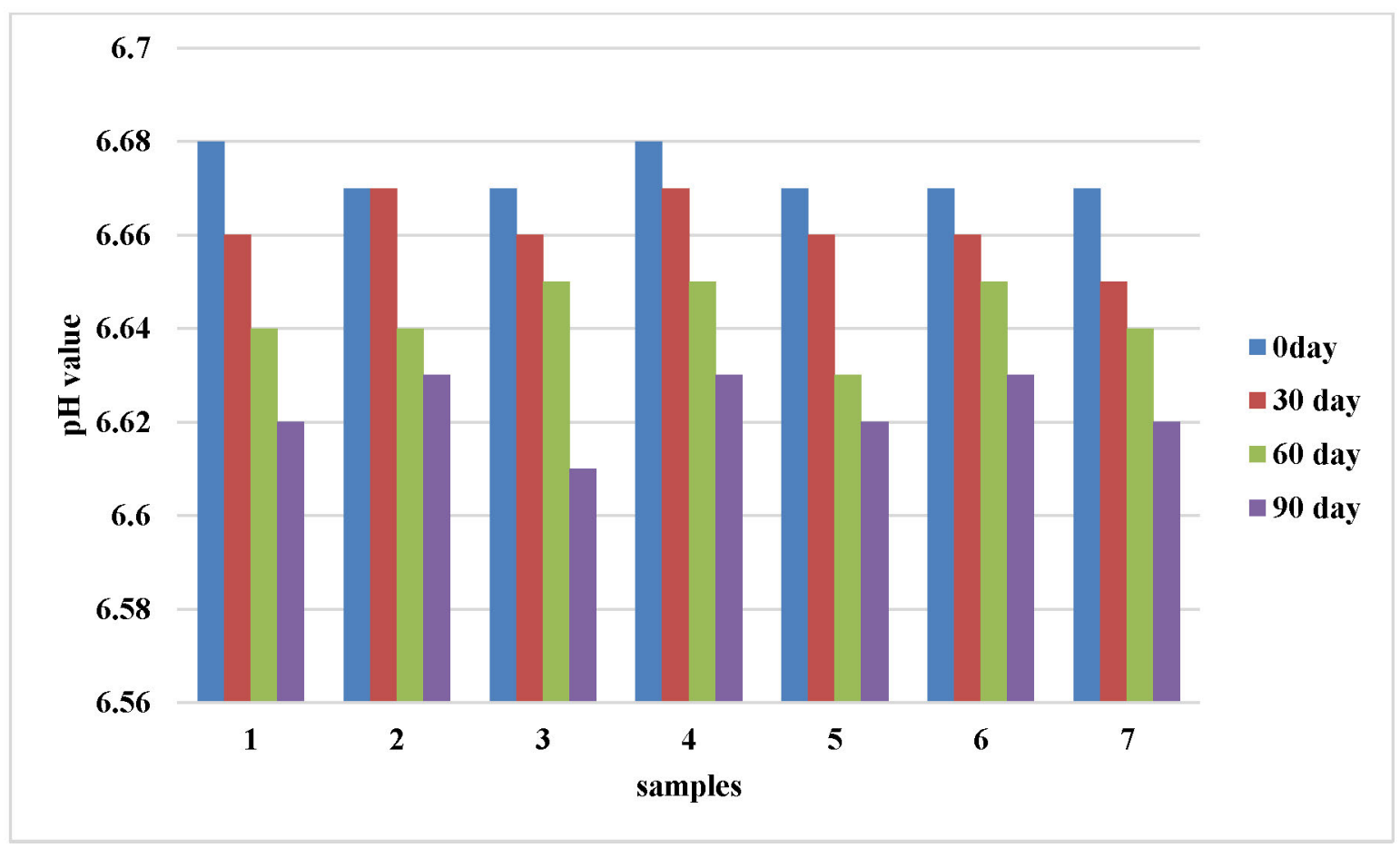

Fig. 2: Change in pH values for UHT milk during storage

1:UHTmilk made from grade A raw milk $100 \%$ by using Midagel stabilizer;2: UHTmilk made from grade B raw milk $100 \%$ by using Midagel stabilizer; 3: UHTmilk made from full fat milk powder(FFMP) 100\% by using Midagel stabilizer ; 4: UHTmilk made from grade A raw milk 50\% + 50\% FFMP by using Midagel stabilizer; 5: UHTmilk made from grade B raw milk 50\% + 50\% FFMP by using Midagel stabilizer;6: UHTmilk made from grade A raw milk 50\% + 50\% FFMP by using Lacta stabilizer and 7: UHTmilk made from grade B raw milk 50\%+50\% FFMP by using Lacta stabilizer

from GB milk after 90 days at $37^{\circ} \mathrm{C}$. Regard to flavor, there were significant differences $(\mathrm{P} \leq 0.05)$ detected in the acceptability scores between panelists. The acceptability of flavour was higher in samples made from GA milk stored at $25^{\circ} \mathrm{C}$ comparing with that stored at $37^{\circ} \mathrm{C}$. The flavour acceptability was lower after 90 days in samples made from GA milk. The result showed that milk stabilizers used has no effect on colour and flavour acceptability of final UHT milk's during storage at different temperature. The results showed that the storage temperature has role in the gelation, flavour and colour of UHT milk. The sedimentation was not observed in samples stored at $25^{\circ} \mathrm{C}$ for 30 days, whereas, it was observed in samples made from GB milk storage at $25^{\circ} \mathrm{C}$ after 60 days. Notwithstanding, the sedimentation was observed in samples stored at $37^{\circ} \mathrm{C}$ after 30 days. The sedimentation was higher in samples made from GB milk when compared with that made using GA or milk powder. It could also be noticed that using of Super Midagel stabilizer in UHT process decreased sedimentation than Lacta 760R in samples made from GB milk (2M and 2L) after 30 days at $25^{\circ} \mathrm{C}$. The obtained results in Table (7) showed that the most effecting factors on the sedimentation in UHT milk were the quality of raw milk used in making UHT milk and storage temperature of final product, while stabilizer type has a little effect.

With increasing the storage period, there is a raise in acidity and viscosity with a decline in $\mathrm{pH}$ (Siddique et al., 2016). In this study, there was increasing of viscosity during storage in all samples (Fig.3) especially at high storage temperature $37^{\circ} \mathrm{C}$. There was a significant effect of stabilizer used on viscosity during storage at $37^{\circ} \mathrm{C}$. Samples made ust ing Super Midagel have low viscosity during storage at $37^{\circ} \mathrm{C}$ for 90 days when compared with samples made using Lacta stabilizer. Chavan, et al., (2011) reported that the storage temperature significantly $(\mathrm{P} \leq 0.05)$ influences the gelation time of UHT milk. Gelation occurs more pronounced at room temperatures $\left(20\right.$ to $\left.25^{\circ} \mathrm{C}\right)$ than at low $\left(4^{\circ} \mathrm{C}\right)$ or at high $(35$ to $40^{\circ} \mathrm{C}$ ) temperatures. Structural of milk protein was changed during storage to form a gel in products stored at $22^{\circ} \mathrm{C}$ and heavy sedimentation could be detected when stored at $40^{\circ} \mathrm{C}$ (Malmgren et al. 2017). Samel et al. (1971) conculcated that the gelation may be inhibited at $37^{\circ} \mathrm{C}$ due to blocking of 
Table 7: Sensory evaluation of UHT milk during storage at different temperatures

\begin{tabular}{|c|c|c|c|c|c|c|}
\hline \multirow{2}{*}{$\begin{array}{l}\text { UHT Milk } \\
\text { samples }\end{array}$} & \multirow{2}{*}{$\begin{array}{c}\text { Time of } \\
\text { storage(Days) }\end{array}$} & \multirow{2}{*}{$\begin{array}{l}\text { Temperature } \\
\text { of storage }\end{array}$} & \multicolumn{4}{|c|}{ Sensory evaluation } \\
\hline & & & Colour & Sedimentation & Flavour & Appearance \\
\hline \multirow[t]{7}{*}{$1 \mathrm{M}$} & 30 & $25^{\circ} \mathrm{C}$ & $4.9 j$ & $0^{\mathrm{a}}$ & $5^{c}$ & $5 \mathrm{e}$ \\
\hline & & $37^{\circ} \mathrm{C}$ & $4.6^{\mathrm{ef}}$ & $1^{b}$ & $4^{b}$ & $4^{\mathrm{d}}$ \\
\hline & 60 & $25^{\circ} \mathrm{C}$ & $4.85^{\mathrm{ij}}$ & $0^{\mathrm{a}}$ & $5^{c}$ & $5^{e}$ \\
\hline & & $37^{\circ} \mathrm{C}$ & $4.5^{\mathrm{de}}$ & $1^{\mathrm{b}}$ & $4^{b}$ & $4^{\mathrm{d}}$ \\
\hline & 90 & $25^{\circ} \mathrm{C}$ & $4.85^{\mathrm{ij}}$ & $0^{\mathrm{a}}$ & $4^{b}$ & $5^{e}$ \\
\hline & & $37^{\circ} \mathrm{C}$ & $4.25^{b}$ & $2 \mathrm{c}$ & $3^{\mathrm{a}}$ & $3 \mathrm{c}$ \\
\hline & Mean & & $4.65^{\mathrm{A}}$ & $0.66^{\mathrm{C}}$ & $4.33^{\mathrm{A}}$ & $4.33^{\mathrm{A}}$ \\
\hline \multirow[t]{7}{*}{$2 \mathrm{M}$} & 30 & $25^{\circ} \mathrm{C}$ & $4.75^{\text {ghi }}$ & $0^{\mathrm{a}}$ & $4^{b}$ & $5^{\mathrm{e}}$ \\
\hline & & $37^{\circ} \mathrm{C}$ & $4.25^{\mathrm{b}}$ & $2^{c}$ & $3^{\mathrm{a}}$ & $3^{c}$ \\
\hline & 60 & $25^{\circ} \mathrm{C}$ & $4.7^{\mathrm{fgh}}$ & $1^{b}$ & $4^{b}$ & $4^{\mathrm{d}}$ \\
\hline & & $37^{\circ} \mathrm{C}$ & $4.5^{\mathrm{de}}$ & $3^{\mathrm{d}}$ & $3^{\mathrm{a}}$ & $2^{b}$ \\
\hline & 90 & $25^{\circ} \mathrm{C}$ & $4.65^{\mathrm{fg}}$ & $2^{c}$ & $4^{b}$ & $3^{c}$ \\
\hline & & $37^{\circ} \mathrm{C}$ & $4^{\mathrm{a}}$ & $4^{e}$ & $3^{\mathrm{a}}$ & $1.5^{\mathrm{a}}$ \\
\hline & Mean & & $4.47^{\mathrm{B}}$ & $2^{\mathrm{B}}$ & $3.50^{\mathrm{B}}$ & $3.08^{\mathrm{B}}$ \\
\hline \multirow[t]{7}{*}{$3 \mathrm{M}$} & 30 & $25^{\circ} \mathrm{C}$ & $4.75^{\text {ghi }}$ & $0^{\mathrm{a}}$ & $4^{b}$ & $5^{e}$ \\
\hline & & $37^{\circ} \mathrm{C}$ & $4.5^{\mathrm{de}}$ & $1^{b}$ & $3^{a}$ & $4^{\mathrm{d}}$ \\
\hline & 60 & $25^{\circ} \mathrm{C}$ & $4.6^{\mathrm{ef}}$ & $0^{\mathrm{a}}$ & $4^{b}$ & $5^{e}$ \\
\hline & & $37^{\circ} \mathrm{C}$ & $4.5^{\mathrm{de}}$ & $1^{b}$ & $3^{\mathrm{a}}$ & $4^{\mathrm{d}}$ \\
\hline & 90 & $25^{\circ} \mathrm{C}$ & $4.5^{\mathrm{de}}$ & $0^{\mathrm{a}}$ & $3^{\mathrm{a}}$ & $5^{\mathrm{e}}$ \\
\hline & & $37^{\circ} \mathrm{C}$ & $4.25^{\mathrm{b}}$ & $2^{c}$ & $3^{\mathrm{a}}$ & $3 \mathrm{c}$ \\
\hline & Mean & & $4.51^{\mathrm{B}}$ & $0.66^{\mathrm{C}}$ & $3.33^{\mathrm{C}}$ & $4.33^{\mathrm{A}}$ \\
\hline \multirow[t]{7}{*}{$1 \mathrm{~L}$} & 30 & $25^{\circ} \mathrm{C}$ & $4.9^{j}$ & $0^{\mathrm{a}}$ & $5^{c}$ & $5^{\mathrm{e}}$ \\
\hline & & $37^{\circ} \mathrm{C}$ & $4.65^{\mathrm{fg}}$ & $1^{\mathrm{b}}$ & $4^{b}$ & $4^{\mathrm{d}}$ \\
\hline & 60 & $25^{\circ} \mathrm{C}$ & $4.9^{j}$ & $0^{\mathrm{a}}$ & $5^{\mathrm{c}}$ & $5^{e}$ \\
\hline & & $37^{\circ} \mathrm{C}$ & $4.5^{\mathrm{de}}$ & $1^{b}$ & $4^{b}$ & $4^{\mathrm{d}}$ \\
\hline & 90 & $25^{\circ} \mathrm{C}$ & $4.85^{\mathrm{ij}}$ & $0^{\mathrm{a}}$ & $4^{b}$ & $5^{e}$ \\
\hline & & $37^{\circ} \mathrm{C}$ & $4.2^{\mathrm{b}}$ & $3^{\mathrm{d}}$ & $3^{\mathrm{a}}$ & $2^{b}$ \\
\hline & Mean & & $4.66^{\mathrm{A}}$ & $0.83^{\mathrm{C}}$ & $4.16^{\mathrm{AB}}$ & $4.16^{\mathrm{A}}$ \\
\hline \multirow[t]{7}{*}{$2 \mathrm{~L}$} & 30 & $25^{\circ} \mathrm{C}$ & $4.8^{\text {hij }}$ & $1^{b}$ & $4^{b}$ & $4^{\mathrm{d}}$ \\
\hline & & $37^{\circ} \mathrm{C}$ & $4.3^{\mathrm{bc}}$ & $3^{\mathrm{d}}$ & $3^{a}$ & $2^{b}$ \\
\hline & 60 & $25^{\circ} \mathrm{C}$ & $4.8^{\mathrm{hij}}$ & $1^{\mathrm{b}}$ & $4^{b}$ & $4^{\mathrm{d}}$ \\
\hline & & $37^{\circ} \mathrm{C}$ & $4.5^{\mathrm{de}}$ & $3^{\mathrm{d}}$ & $3^{a}$ & $2^{b}$ \\
\hline & 90 & $25^{\circ} \mathrm{C}$ & $4.6^{\mathrm{ef}}$ & $2^{c}$ & $4^{b}$ & $3^{c}$ \\
\hline & & $37^{\circ} \mathrm{C}$ & $4^{\mathrm{a}}$ & $4^{\mathrm{d}}$ & $3^{\mathrm{a}}$ & $1.4^{\mathrm{a}}$ \\
\hline & Mean & & $4.50^{\mathrm{B}}$ & $2.33^{\mathrm{A}}$ & $3.50^{\mathrm{BC}}$ & $2.75^{\mathrm{B}}$ \\
\hline \multirow[t]{7}{*}{$3 \mathrm{~L}$} & 30 & $25^{\circ} \mathrm{C}$ & $4.75^{\text {ghi }}$ & $0^{\mathrm{a}}$ & $4^{b}$ & $5^{e}$ \\
\hline & & $37^{\circ} \mathrm{C}$ & $4.5^{\mathrm{de}}$ & $1^{b}$ & $4^{b}$ & $4^{\mathrm{d}}$ \\
\hline & 60 & $25^{\circ} \mathrm{C}$ & $4.6^{\mathrm{ef}}$ & $0^{\mathrm{a}}$ & $4^{b}$ & $5^{e}$ \\
\hline & & $37^{\circ} \mathrm{C}$ & $4.4^{\mathrm{cd}}$ & $1^{b}$ & $3^{\mathrm{a}}$ & $4^{\mathrm{d}}$ \\
\hline & 90 & $25^{\circ} \mathrm{C}$ & $4.5^{\mathrm{de}}$ & $0^{\mathrm{a}}$ & $3^{\mathrm{a}}$ & $5^{e}$ \\
\hline & & $37^{\circ} \mathrm{C}$ & $4.25^{b}$ & $2^{c}$ & $3^{\mathrm{a}}$ & $3^{c}$ \\
\hline & Mean & & $4.50^{\mathrm{B}}$ & $0.66^{\mathrm{C}}$ & $3.50^{\mathrm{BC}}$ & $4.33^{\mathrm{A}}$ \\
\hline
\end{tabular}

M: refer to Super Midagel stabilizer using in UHT process, L: Refer to Lacta stabilizer using in UHT process 1M: UHTmilk made from grade A raw milk 100\% by using Midagel stabilizer;2M: UHTmilk made from grade B raw milk $100 \%$ by using Midagel stabilizer; 3M: UHTmilk made from full fat milk powder(FFMP) $100 \%$ by using Midagel stabilizer, 1L: UHTmilk made from grade A raw milk 100\% by using Lacta stabilizer;2L: UHTmilk made from grade B raw milk 100\% by using Lacta stabilizer; 3L: UHTmilk made from full fat milk powder(FFMP) $100 \%$ by using Lacta stabilizer

Means with the same letter(s) in the same column are not significant, but different letters are significant $(\mathrm{P}<0.05)$

Capital letters refer to differences among treatments,

Small letters: refer to differences among storage times at different temperature in the same column 


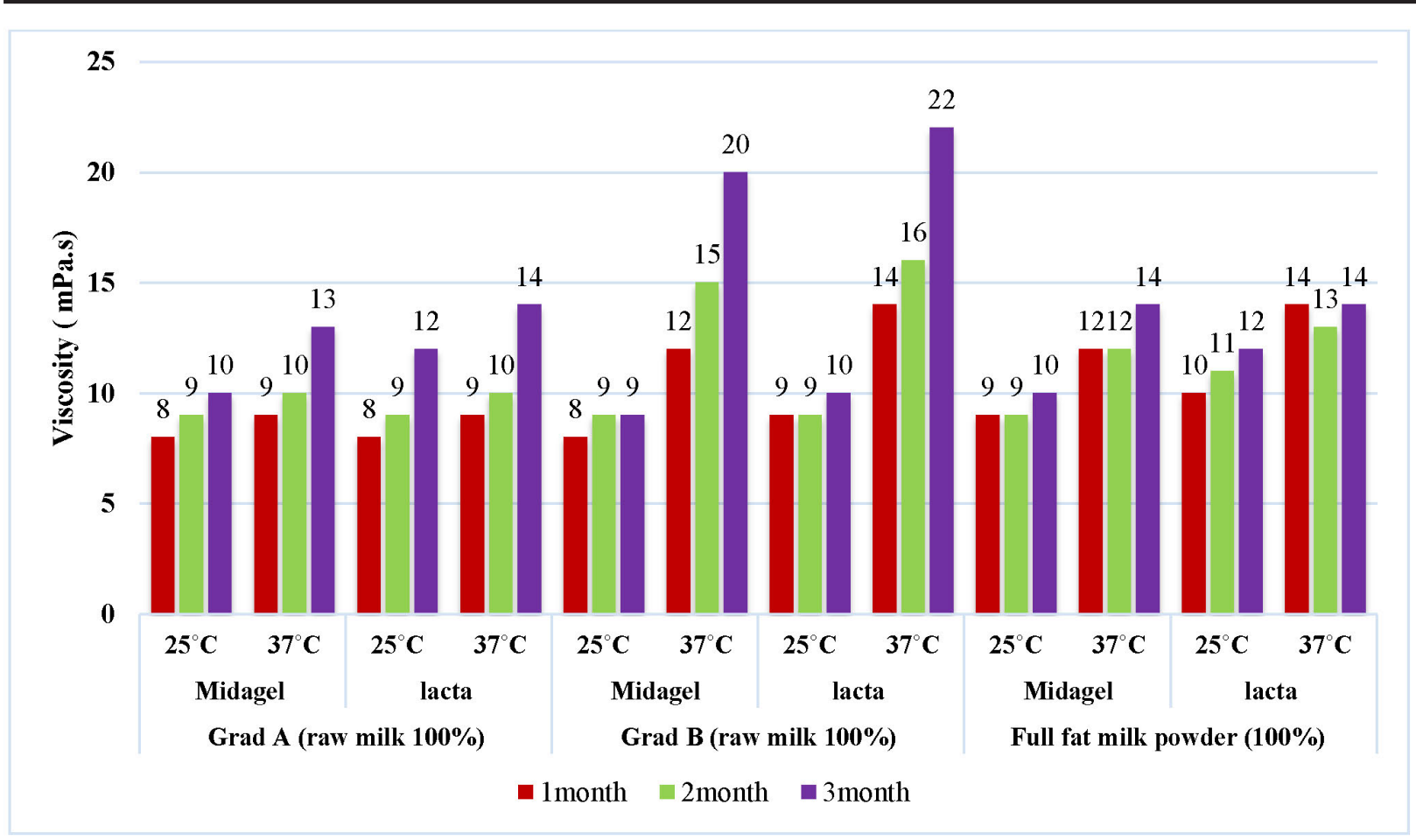

Fig. 3: Change in viscosity of UHT milk treatments during storage at different temperature

protein-protein interactions by casein-lactose interactions involving lysine residues. The browning observed in UHT milk stored at $37^{\circ} \mathrm{C}$. The results of this study showed that the gelation or protein sedimentation was more pronounced in milk stored at $37^{\circ} \mathrm{C}$ when compared to that stored at $25^{\circ} \mathrm{C}$. This was not in agreement with the hypothesis of Samel et al. (1971). On the other hand, the brown color of Maillard reaction and protein gelation are more pronounced in UHT milk made using hydrolyzed lactose than in that made using non-hydrolyzed lactose. Brownness of milk increased during storage of hydrolyzed-lactose UHT milk, which may be caused by Maillard-reaction. The formation of late-stage Millard products could also explain the increasing of the gel during storage time (Nielsen et al. 2017). So, the sedimentation in UHT GB milk is directly related to the low quality of raw milk, and storage temperature at higher than $25^{\circ} \mathrm{C}$ ) in direct heating UHT milk.

\section{SDS-PAGE of samples after storage for 90 days}

SDS-PAGE was used to investigate the effects of storage (3 months) on protein profile of UHT milk treatments. It was studied the differences between total milk proteins and protein that precipitated on the wall of milk package. Results in (Fig.4) and the analysis of gel by Total Lab recommended no significant $(\mathrm{P} \geq 0.05)$ differences among all UHT treatments after storage period ( 3 months). As well as,
SDS-PAGE showed that no differences between soluble milk proteins and precipitated proteins on the wall of packages. Nielsen et al. (2017) studied the effect of indirect UHT process on milk proteins and they found that whey protein bands corresponding to the positions of $\alpha$-lactalbumin and $\beta$-lactoglobulin were missing in the lower part of the gel, indicating that these two whey proteins become part of disulphide crosslinked aggregates during processing. In this study, no significant proteolysis was found in all stored samples for 90 days, compared to fresh sample. The proteolysis of UHT milk proteins is mainly of two origins: the plasmin (native milk alkaline proteinase) and heat-stable bacterial proteinases. These two groups of proteinases hydrolyze the milk proteins to reduce the stability of UHT milk during its shelf life (Datta \& Deeth 2003). However, plasmin activity could be reduced by heat treatment at high temperatures for relatively long times such as in indirect UHT plants (Kelly \& Foley 1997, Cauvin et al., 1999). From these results it could be concluded that no proteolysis caused in UHT milk proteins during storage period and the sedimentation of proteins may be related to some change in physicochemical properties of milk proteins.

\section{RP-HPLC of samples after storage for 90 days}

The 12\% TCA filtrates of samples were separated by RP-HPLC (Figs. 5-6). No significant differences among all treatments. This indicated that 


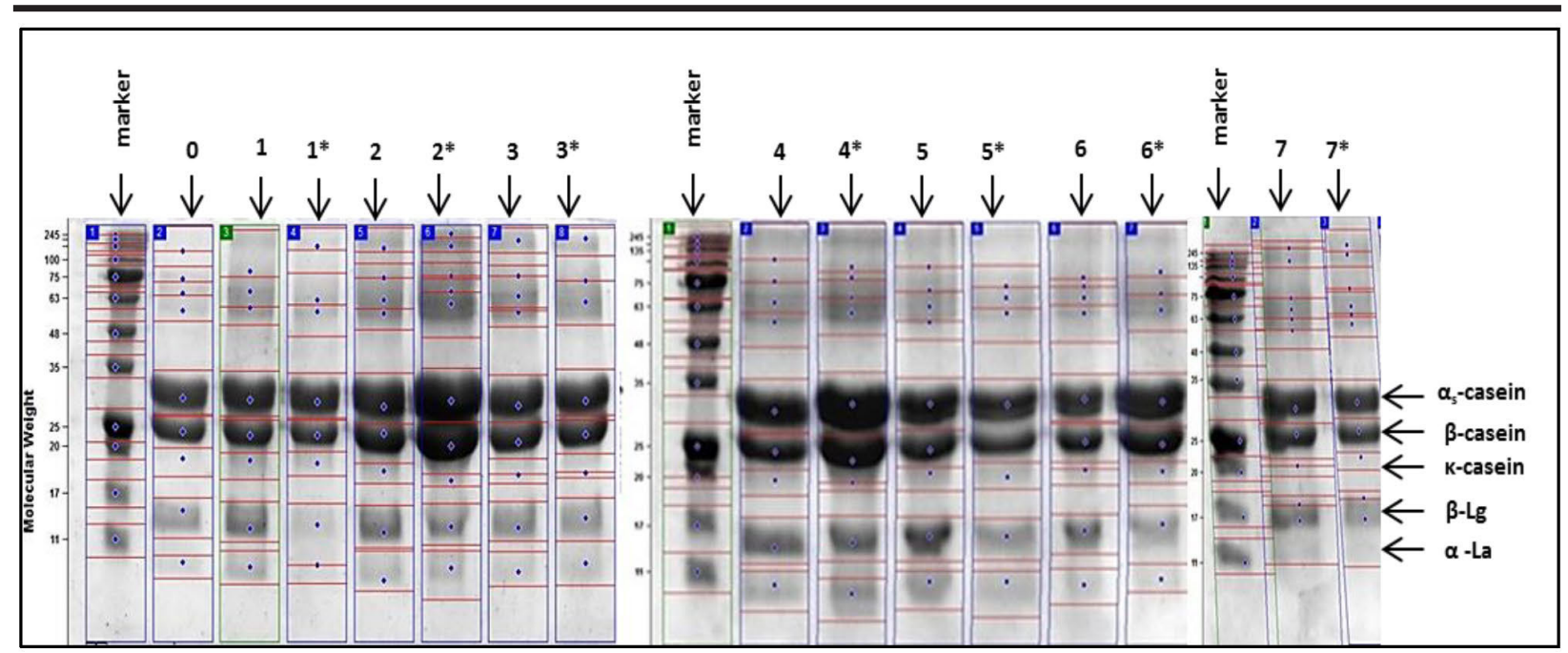

Fig. 4: SDS-PAGE (12.5\% T) of UHT milk treatments

Sample No. 0 (Fresh UHT milk), 1:UHTmilk made from grade A raw milk 100\% by using Midagel stabilizer;2: UHTmilk made from grade B raw milk $100 \%$ by using Midagel stabilizer; 3: UHTmilk made from full fat milk powder(FFMP) 100\% by using Midagel stabilizer ; 4: UHTmilk made from grade A raw milk 50\% + 50\% FFMP by using Midagel stabilizer; 5: UHTmilk made from grade B raw milk 50\% + 50\% FFMP by using Midagel stabilizer;6: UHTmilk made from grade A raw milk 50\% + 50\% FFMP by using Lacta stabilizer and 7: UHTmilk made from grade B raw milk 50\% + 50\% FFMP by using Lacta stabilizer.

Molecular weight $=\mathrm{KD}$

(*) refer to the samples from precipitated protein in UHT milk packages

$230 \mathrm{~nm}$

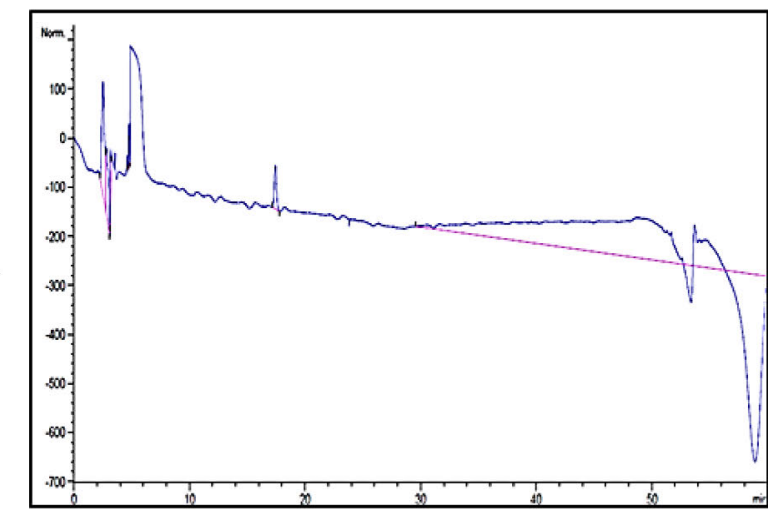

(0)

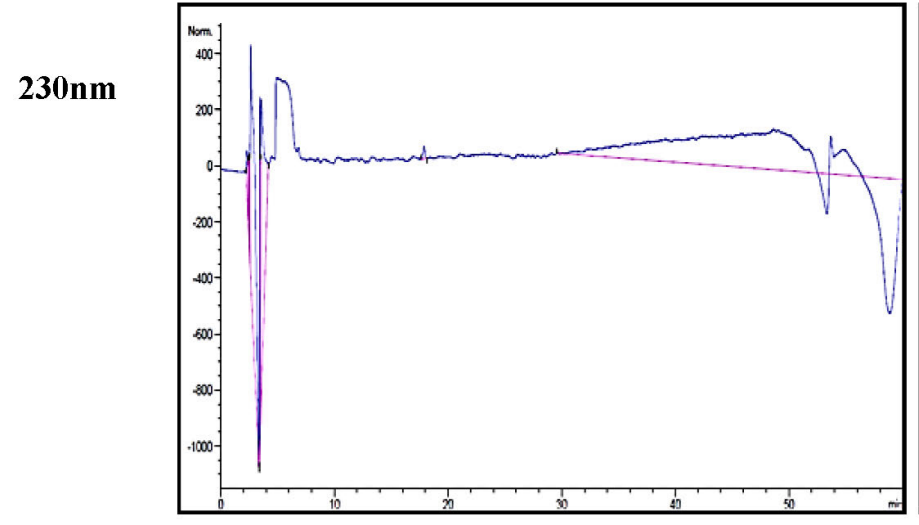

(2)

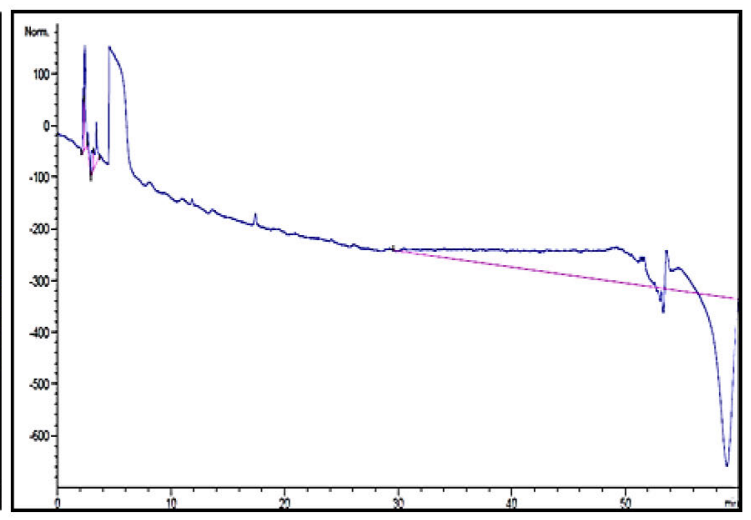

(1)

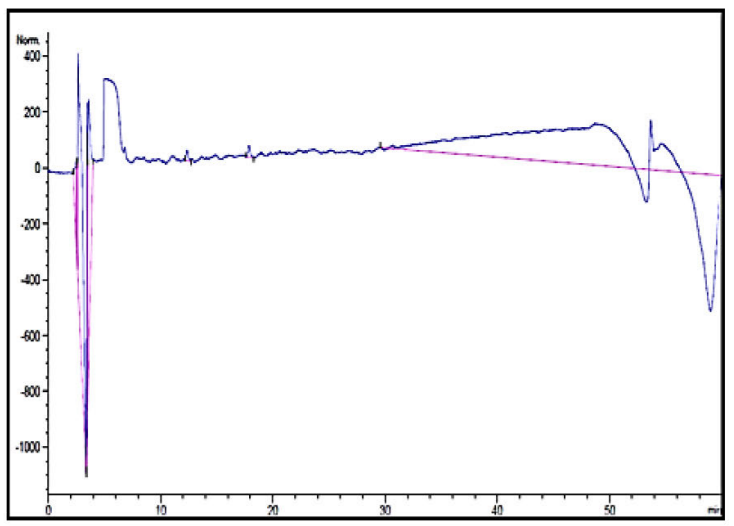

(3)

Fig.5: RP-HPLC for TCA filtrates of UHT milk samples

0: Fresh milk ; 1:UHTmilk made from grade A raw milk 100\% by using Midagel stabilizer;2: UHTmilk made from grade B raw milk 100\% by using Midagel stabilizer; 3: UHTmilk made from full fat milk powder(FFMP) $100 \%$ by using Midagel stabilizer after storage for 90 day. 


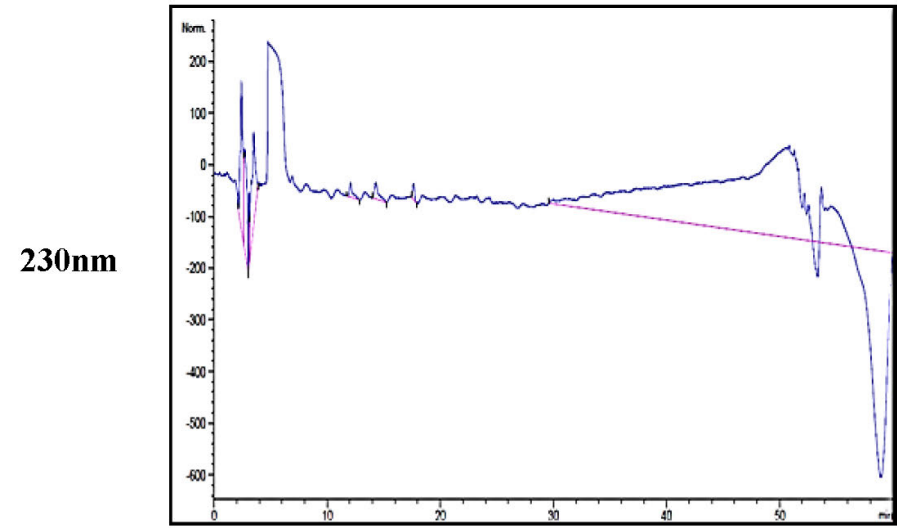

(4)

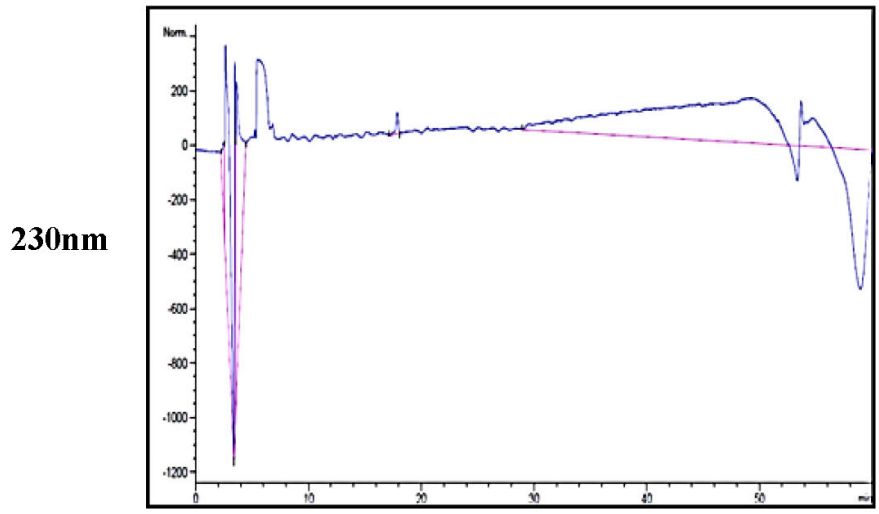

(6)

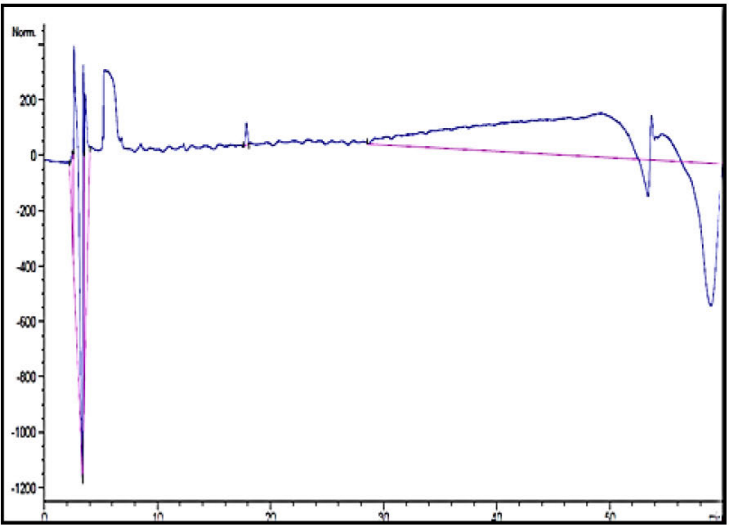

(5)

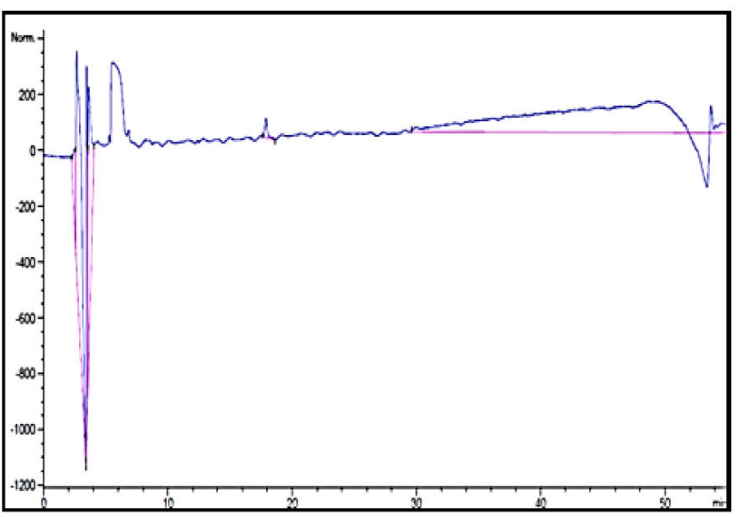

(7)

Fig. 6: RP-HPLC for TCA filtrates of UHT milk samples

4: UHTmilk made from grade A raw milk 50\% +50\% FFMP by using Midagel stabilizer; 5: UHTmilk made from grade B raw milk 50\% + 50\% FFMP by using Midagel stabilizer;6: UHTmilk made from grade A raw milk 50\% + $50 \%$ FFMP by using Lacta stabilizer and 7: UHTmilk made from grade B raw milk $50 \%+50 \%$ FFMP by using Lacta stabilizer after storage for 90 day.

there were no significant differences in proteolytic systems either milk enzymes or microbial enzymes. Since the total bacterial count and spore forming bacteria were significantly higher in GB milk than those of GA milk, the low molecular weight peptides may be further degraded and not appeared at RP-HPLC profiles. This finding may be recommended by the sedimentation of GB samples.

Low quality milk is more susceptible to gel formation than high quality milk. Microorganisms that produce heat-stable enzymes cause the most serious gelation problems (Chavan et al., 2011). The results of SDS-PAGE and RP-HPLC did not show any proteolysis in UHT milk made using low quality milk. This finding suggested that the sedimentation of UHT milk is related to many other factors such as ionic strength, protein structure, storage temperature and direct or indirect heating system.

\section{CONCLUSION}

Consumption trends for UHT milk have increased especially in countries with shortage of raw milk. Milk with high microbial count and low quality is more susceptible to gel formation than milk with a low microbial count and high quality. The GB milk contains extremely high numbers of microorganisms due to poor hygienic practices during hand milking in the outdoors and milk handling practices. The sedimentation and fat separation that pronounced in GB UHT milk are not related to the proteolysis but are mostly related to stability of milk proteins and the storage temperature. The direct heating system used in processing UHTmilk in this study increased the sedimentation of GB milk. 


\section{REFERENCES}

Association of official analytical chemists - AOAC. 2007. Official Methods of Analysis. $17^{\text {th }}$ ed. Gaithersburg: AOAC International.

Baglinière F., Tanguy G., Jardin J., Matéos A., Briard V., Rousseau F., RobertB, Beaucher E., Humbert G, Dary A, Gaillard JL, Amiel C., \& Gaucheron F .2012. Quantitative and quali tative variability of the caseinolytic potential of different strains of Pseudomonas fluorescens: Implications for the stability of casein micelles of UHT milks during their storage. Food Chemistry. 135: 2593-2603

Burton, H. 1994. Ultra high temperature processing of milk and milk products. Chapman \& Hall, London, UK. Springer Science ISBN: 97814615-2157-0.

Cauvin, E., Sacchi, P., Rasero, R., \& Turi, RM. 1999. Proteolytic activity during storage of UHT milk. Industri Alimentari, 38: 825-829.

Chavan, R.S., Chavan, S.R., Khedkar, C.D., \& Jana, A.H. 2011. UHT Milk Processing and Effect of Plasmin Activity on Shelf Life: A Review. Comprehensive Reviews in Food Science and Food Safety, 10: 251-268

Chen, B., Grandison, A.S., \& Lewis, M.J. 2015. Effect of seasonal variation on some physical properties and heat stability of milk subjected to ultra-high temperature and in-container sterilization. Food Chemistry. 181: 227-234

Clare, D. A., Bang, W.S., Cartwright, G., Drake. M. A., Coronel, P., \& Simunovic, J. 2005. Comparison of sensory, microbiological, and biochemical parameters of microwave verses indirect UHT fluid skim milk during storage. Journal of Dairy Science. 88: 4172-4182

Codex Alimentarius. 2007. Codex Standard for milk powders and cream powder, 207-1999. Milk and Milk Products. First edition, ISBN 978-92-5-105837-4. World health organization food and agriculture organization of the united nations, Rome.

Contarini, G., Povolo, M., Leardi, R., \& Toppino, P.M. 1997. Influence of heat treatment on the volatile compounds of milk. Journal of Agriculture and Food Chemistry, 45:3171-3177.

Datta, N., \& Deeth, H.C. 2003. Diagnosing the cause of proteolysis in UHT milk. Lebensmittelwissenschaft und Technology, 36: 173-182.
Datta, N., \& Deeth, H.C. 2001. Age gelation of UHT milk e a review. Trans IChemE, 79:197-210.

Datta, N., Elliott AJ, Perkins M L, \& Deeth HC (2002) Ultra-high-temperature (UHT) treatment of milk: Comparison of direct and indirect modes of heating. Australian Journal of Dairy Technology, 57: 211-227

Deeth, H.C. 2010. Improving UHT Processing and UHT Milk Products. In: Improving the Safety and Quality of Milk. Griffiths MW (ed). Volume 1: Milk production and processing. Woodhead Publishing Limited, Cambridge UK. PP: 302-329

Deharveng, G., \& Nielsen, S. S. 1991. Partial purification and characterization of native plasminogen activators from bovine milk, Journal of Dairy Science, 7: 2060-2072

Egyptian standard.2005. Long life sterilized milk, ES: 1623/2005. Egyptian organization for standardization and quality control.

Egyptian Standard.2010. Essential requirements for milk \& milk products, ES: 7123/2010. Egyptian organization for standardization and quality control.

Hames, B.D., \& Rickwood, D. 1990. In: Gel electrophoresis of proteins. A practical approach. TRL, Puplishing C, London, England. PP: 34-48.

IDF 99-2. 2009. Milk and milk products - Sensory analysis - Part 2: Recommended methods for sensory evaluation. IDF standard 99-2:2009/ ISO 22935-2. International Dairy Federation, Brussels Belgium.

International Standard Organization. 2003. Microbiology of food and animal feeding stuffsHorizontal method for the enumeration of microorganisms - colony count technique at $30^{\circ} \mathrm{C}$ ISO: 4833.

International Standard Organization. 2009. Microbiology of food and animal feeding stuffsHorizontal method for the enumeration of colony-forming units (CFU) of specially thermoresistant spores of thermophilic bacteria ISO/TS 27265.

Kelly, A. L., \& Fox, P.F. 2012. Biochemistry of Milk Processing. In: Food Biochemistry and Food Processing. Simpson BK (ed) ( $2^{\text {nd }}$ ed) Wiley \& Sons, Inc Ames, USA. PP: 465-490. 
Kelly, A.L., \& Foley, J. 1997. Proteolysis and storage stability of UHT milk as influenced by plasmin activity, plasmin/ $\beta$-lactoglobulin complexation, plasminogen activation and somatic cell count. International Dairy Journal, 7: 411-420.

Kessler, H.G. 2002. Heat Treatment, Processes and Effects - Microorganisms and Conditions of Inactivation. In: Food and Bio Process Engineering - Dairy Technology (5 $5^{\text {th }}$ ed) Verlag A Kessler, Munich, Germany. PP: 65-147.

Laemmli, U. K. 1970. Cleavage of structural proteins during the assembly of the head of bacteriophage T4. Nature, 277: 680-685.

Malmgren, B., Langton, Y.A.M., Altsköar, A. ,Bremer, MGEG., Dejmek, P., \& Paulsson, M. 2017.Changes in proteins, physical stability and structure in directly heated UHT milk during storage at different temperatures. International Dairy Journal, 71: 60-75

Mayr, R., Gutser, K., Busse, M. \& Seiler, H. 2004. Gram positive non-sporeforming recontaminants are frequent spoilage organisms of German retail ESL (extended shelf life) milk. Milchwissenschaft, 59: 262-266.

McMahon, D.J. 1996. Age-gelation of UHT milk: Changes that occur during storage, their effect on shelf life and the mechanism by which gelation occurs heat treatments and alternative methods. In Proceedings of IDF symposium, Vienna, Austria. PP: 315-326.

Nielsen, S.D., Jansson, T., Le, T.T., Jensen, S., Eggers, N., Rauh, V., Sundekilde, U.K., Sørensen, J., Andersen, H.J., Bertram, H.C., \& Larsen, LB. 2017. Correlation between sensory properties and peptides derived from hydrolysed-lactose UHT milk during storage. International Dairy Journal, 68: 23-31.
Perkin, A.G., Henschel, M.J., \& Burton, H. 1973. Comparison of milks processed by the direct and indirect methods of ultra-high-temperature sterilization: VI. Effects on sediment formation and clotting with enzymes, Journal Dairy Research, 40: 215-224.

Renner, E. 1988. Storage stability and some nutritional aspects of milk powders and ultra high temperature products at high_ambient temperatures. Journal Dairy Research, 55:122-142.

Samel, R., Weaver, R.W.V., \& Gammack, D.B. 1971. Changes on storage in milk processed by ultra-high-temperature sterilization. Journal Dairy Research, 38:323-332.

Siddique, F., Riffat, S., Arshad, M., Farooq, U., Iftikhar, K., \& Kharal, S. 2016. Effect of storage temperature on the physiochemical properties of Ultra High Temperature (UHT) milk. International Journal of Food and Allied Sciences, 2: 52-57.

Standard Methods for the Examination of Dairy Products. 2010. Standard Methods for the Examination of Dairy products. Edited by Marth. H.Washington, American public Health Association, Inc.

Valero, E., Villamiel, M., Miralles, B., Sanz, J., \& MartõÂnez-Castro, I. 2001. Changes in flavour and volatile components during storage of whole and skimmed UHT milk. Food Chemistry, 72: 51-58.

Walstra, P., Geurts, T. J., Noomen, A., Jellema, A., \& van Boekel, MAJS. 1999. Heat Treatment. In: Dairy Technology-Principles of Milk Properties and Processes. Marcel Dekker, Inc, New York, USA. ISBN: 082470228X-727

Walstra, P., Jenness, R., \& Badings, H.T. 1984. Dairy chemistry and physics. Wiley, NewYork. ISBN: 9780471097792-467. 


\section{تأثير جودة اللبن والمثبتات على بعض الخواص الفيزوكيماوية

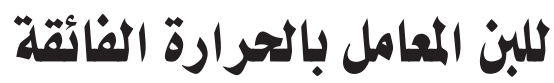

محمود إبراهيه السيد '، أمل أحمد إبراهيمج ، سامع علي عوض

ا قسم بحوث تكنولوجيا تصنيع الألبان - معهد بحوث تكنولوجيا الأغذية- مركز البحوث الزراعية-

\section{r قسهم علوم وتقنية الألبان- كلية الزراعة - جامعة الإسكندرية- مصر.}

تم دراسة تأثير جودة اللبن والمثبتات على التغيرات غير المرغوبة في اللبن المعامل بالحرارة الفائقة (UHT)

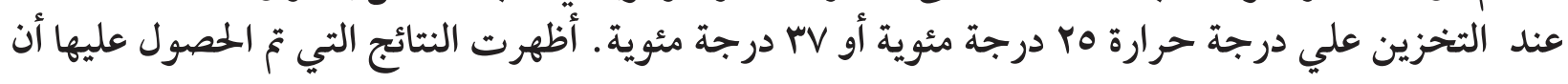
العدد الكلي للميكروبات ،

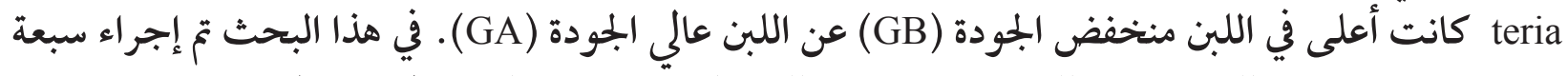

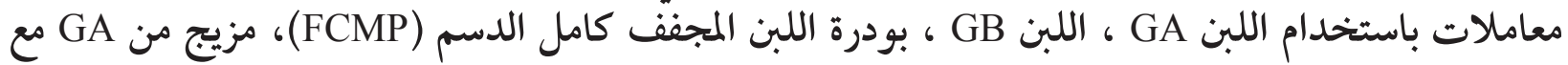

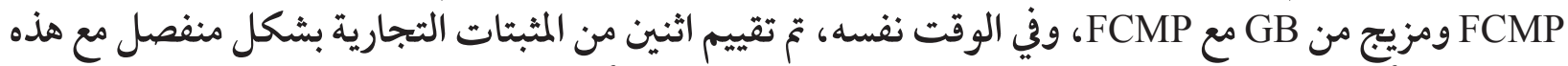

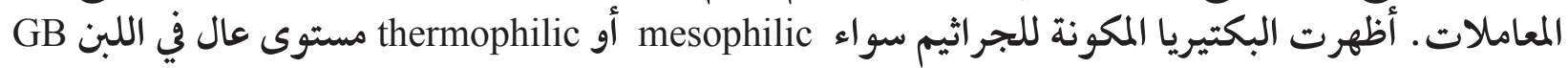

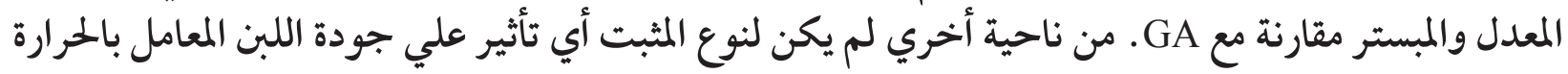

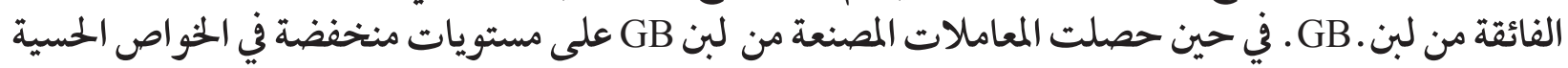

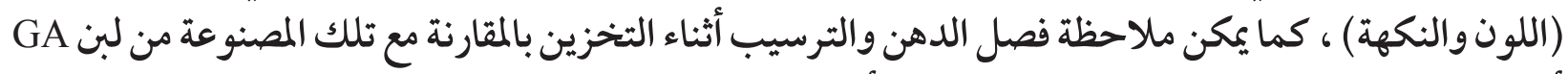

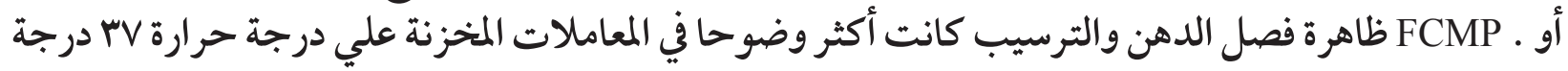

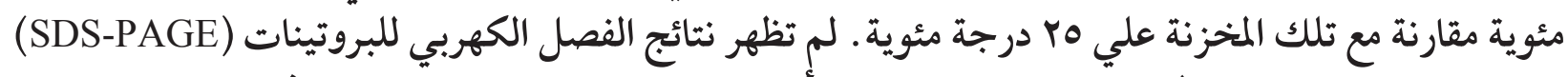

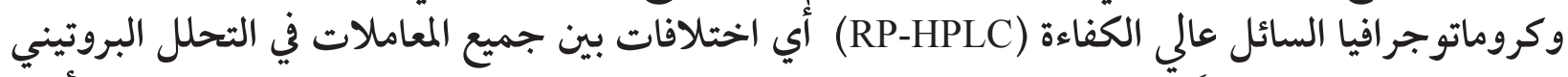

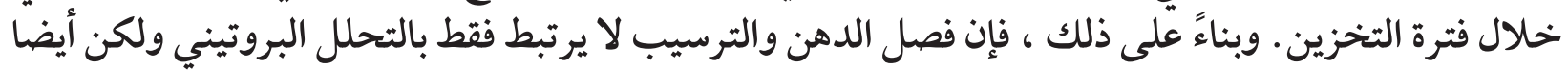

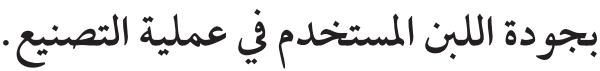

